\title{
ON HUMAN RATIONALITY AND GOVERNMENT CONTROL
}

\author{
EMILE PHANEUF* \\ AND CARMELO FERLITO**
}

Fecha de recepción: 31 de enero de 2014.

Fecha de aceptación: 31 de octubre de 2014.

Resumen: En este artículo abordamos en primer lugar una vieja crítica de la racionalidad humana y lo que ello implica para el papel que desempeña el gobierno. Revisamos y comparamos gran parte de la literatura sobre racionalidad, y demostramos que distintos autores dentro de diversos campos atribuyen cosas muy diferentes a la palabra «racional». Si bien no hacemos ningún tipo de reivindicación respecto a si o no los seres humanos se comportan siempre racionalmente, subrayamos la defectuosa lógica por la que se sugiere el papel del gobierno como una forma de abordar el problema de la irracionalidad humana. Siguiendo la tradición Mises-Rothbard-Huerta de Soto, sostenemos que más importante que la racionalidad perfecta es la acción intencionada. Explicamos la naturaleza dinámica del mercado en la que el tiempo juega un papel importante, y los seres humanos actúan con expectativas para lograr sus metas, aprenden de los errores del pasado, descubren nueva información y modifican sus planes en consecuencia. Utilizando el enfoque de Hayek, se discute el problema del conocimiento en el que los datos están dispersos entre millones de individuos (desconocidos en su totalidad para cualquier autoridad central), así como los problemas con la aplicación del método científico tal y como se utiliza en las ciencias de la naturaleza a las ciencias del comportamiento humano. Estos problemas combinados, sostenemos, generan un sistema mucho más desastroso de lo que sería un sistema en el que los individuos con frecuencia irracionales

* Export Manager for an American manufacturer in the mining industry. MA in Political Science from University of Arkansas, Fayetteville.

E-mail: emileaphaneuf@gmail.com.

** Senior Fellow, Institute for Democracy and Economic Affairs, Kuala Lumpur, and Visiting Professor, INTI International College Subang, Subang Jaya, Malaysia. Correspondence address: BT-11-8 Saujana Residency, Jalan SS16/1, 47500 Subang Jaya, Malaysia. E-mail: carmelo.ferlito@gmail.com. 
fuesen libres para cometer errores por sí mismos, descubrir nueva información y tomar acciones para su propia mejora.

Palabras clave: Racionalidad, Intervención del Gobierno, Equilibrio, Acción Humana, Comportamiento Intencionado.

Clasificación JEL: B53, D80, D84, H10, H30.

Abstract: In this paper we first address a long-standing criticism of human rationality and what that means for the role of government. We review and compare much of the literature on rationality and demonstrate that various authors within various fields often mean very different things by the word «rational.» While we make no claims as to whether or not humans always behave rationally, we point out the flawed logic for what is suggested for the role of government as a way of addressing the human irrationality problem. Building on the Mises-Rothbard-Huerta de Soto tradition, we argue that what is more important than perfect rationality is purposeful action. We explain the dynamic nature of the market in which time plays an important role, and humans act with expectations to accomplish goals, learn from past mistakes, discover new information and modify their plans accordingly. Using Hayek's approach, we discuss the knowledge problem in which data is dispersed among millions of individuals (unknown in its entirety to any central authority) as well as the problems with applying the scientific method exactly as it is used in the natural sciences to the human behavioral sciences. These problems combined, we argue, make for a much more disastrous system than would be a system in which oftenirrational individuals would be free to make mistakes for themselves, discover new information and take actions for their own betterment.

Key words: Rationality, Government Intervention, Equilibrium, Human Action, Purposeful Behaviour.

JEL Classification: B53, D80, D84, H10, H30.

CONFLICT OF VISIONS AND RATIONALITY

Why do beliefs cluster the way they do?

If someone believes that only police and military should have guns, why is that person also likely to support socialized 
healthcare, a government-imposed minimum wage, and be unsupportive of school vouchers? In his 1987 book A Conflict of Visions: Ideological Origins of Political Struggles, economist Thomas Sowell put forth two conflicting visions of man that he believes explain many of the underlying reasons for the clustering of beliefs.

In Sowell's "Constrained Vision", man's nature is flawed, selfish and fixed. It seeks to deal with the flaws of man's nature by erecting institutions with restraints: separation of powers, constitutions, etc. Those who employ the Constrained Vision see abuses of power by leaders (Napoleon Bonaparte, Kim Jongun, and yes - most political leaders of modern democratic nations) as inevitable due to the shortfalls of man's nature. For this reason, limitations must be placed on the institutions themselves so that it is more difficult for any one individual to abuse them. The idea is to decentralize power so that man's flaws are not catastrophic.

The «Unconstrained Vision», by contrast, sees abuses of power as being caused by not having chosen the right leaders or established the right kinds of institutions. "Implicit, - writes Sowell (2007, p. 18) - is the notion that the potential is very different from the actual, and that means exist to improve human nature toward its potential, or that such means can be evolved or discovered, so that man will do the right thing for the right reason rather than for ulterior psychic or economic rewards». And central to the Unconstrained Vision is the notion that human beings are highly malleable and can be trained in the service of some ideal.

Steven Pinker's 2002 book The Blank Slate: The Modern Denial of Human Nature builds on much of Sowell's work. He refers to Sowell's Constrained and Unconstrained Visions as the Tragic and Utopian Visions, respectively. He argues that much of the Unconstrained Vision is rooted in the false belief that individuals are born with no pre-programmed software (or innate human nature). This blank slate (or tabula rasa) belief, he explains, was often based on good intentions. After all, if we are born equal in every way, this could eradicate inequality, but the problem is that the human mind does, in fact, come with certain innate biological programming, as the human behavioral sciences have already demonstrated. The following two paragraphs, in Pinker's 
own words, explain the two visions and key intellectuals associated with each:

In the Tragic Vision, humans are inherently limited in knowledge, wisdom, and virtue, and all social arrangements must acknowledge those limits. «Mortal things suit mortals best, » wrote Pindar; «from the crooked timber of humanity no truly straight thing can be made,» wrote Kant. The Tragic Vision is associated with Hobbes, Burke, Smith, Alexander Hamilton, James Madison, the jurist Oliver Wendell Holmes Jr., the economists Friedrich Hayek and Milton Friedman, the philosophers Isaiah Berlin and Karl Popper, and the legal scholar Richard Posner.

[...]

In the Utopian Vision, psychological limitations are artifacts that come from our social arrangements, and we should not allow them to restrict our gaze from what is possible in a better world. Its creed might be "Some people see things as they are and ask "why?"; I dream things that never were and ask "why not?"» The quotation is often attributed to the icon of 1960s liberalism Robert F. Kennedy, but was originally penned by the Fabian socialist George Bernard Shaw (who also wrote, «There is nothing that can be changed more completely than human nature when the job is taken in hand early enough»). The Utopian Vision is also associated with Rousseau, Godwin, Condorcet, Thomas Paine, the jurist Earl Warren, the economist John Kenneth Galbraith, and to a lesser extent the political philosopher Ronald Dworkin. (Pinker, 2002, pp. 287-288).

We could summarize the visions as follows (Table 1). ${ }^{1}$

None of this is to say that a given person cannot hold political beliefs characterized by both visions. This is often the case. «Not all social thinkers fit this schematic dichotomy. John Stuart Mill and Karl Marx, for example, do not fit for very different reasons». And, we add, Hayek's and Popper's positions are much more complex than what could be argued from the table. "Others take midway positions between the two visions, or convert from one to the other. However, the conflict of visions is no less real because

${ }^{1}$ Much of the content for this section including the table was reused with permission from the Foundation for Economic Education from Phaneuf (2013). 
TABLE 1

Unconstrained/Utopian Vision of Man
Sees man's nature as malleable and
perfectible.
Believes that society should be led by
the strongest and most capable among
us and under the right institutions.

Judges laws by their intentions.

Favors human action motivated by selflessness and sincerity.

Constrained/Tragic Vision of Man

Sees man's nature as flawed, selfish and fixed.

Believes that all people should be
restrained in what they should be able
to do. Believes political leaders to be of
the same flawed, selfish and fixed
nature as everyone else, thus the
importance of separation of powers,
constitutions, etc.

Judges laws by their effects.

Less concerned with motives behind human action as long as interactions between individuals are positive-sum.

Sees racism, crime, etc. as a sociallySees racism, crime, etc. as just part of learned phenomenon. man's flawed, selfish, and fixed nature.

Seeks to explain the causes of war, poverty, crime.

Sees war, poverty and crime as having been the norm throughout human history (due to man's flawed, selfish and fixed nature) and instead seeks to explain the causes of peace, wealth, law and order and morality.

Sees market economies as «obeying the power of particular interests, and should therefore be made in the future to obey the power of the public interest» (Robinson, 2008, p. 9). This vision seeks to define the public interest by itself.

Seeks economic and social equality «even if the means chosen imply great inequality in the right to decide such issues and choose such means» (Sowell, 2007, p. 55).

Points to human irrationality as proof that the strongest and most capable among us must lead.

Sees market economies as «responsive to systemic forces, the interaction of innumerable individual choices and performances» (Robinson, 2008, p. 9).

Seeks equality through freedom of choice.

Less concerned with whether or not individuals always behave rationally. Emphasizes that leaders come from the same pool of flawed, selfish and fixed human beings. 
everyone has not chosen sides or irrevocably committed themselves» ${ }^{2}$ (2007, p. 33). As Pinker (2002, p. 287) explains, «[n]ot every ideological struggle fits [Sowell's] scheme, but as we say in social science, he has identified a factor that can account for a large proportion of the variance».

What is relevant from Sowell's Visions to the topic of this paper is the question concerning human rationality (see the bottom row in the table). In fact, it could be said, that this paper spawned as a response to the common critiques about rationality of intellectuals and schools of thought said to be proponents of free markets. Many of us have heard statements like «the problem with Milton Friedman's work is that it assumes that humans behave rationally», or "the problem with the Austrian school of economics is that it is based upon the fallacy that humans are rational actors» ${ }^{3}$.

Sowell's A Conflict of Visions gives valuable insight into how rationality is seen by economists, which is worth quoting in length.

Classical and neo-classical economics, especially of the Austrian school, exemplify this constrained vision of systemic rationality, in which individual articulation means little. In an uncontrolled market, as seen in this vision, changing prices, wages, and interest rates adjust the economy to shifting demands, technological changes, and evolving skills- without any of the actors in this drama knowing or caring how his individual responses affect the whole. It can be analyzed as a general process of interaction with its own characteristic patterns and results - otherwise there would be no Austrian economics- but cannot be specified in such concrete detail as to make it feasible for any individual or group to plan or control the actual process. The rationality in it is systemic, not individual - and such individual rationality as may exist is largely incidental, so that the much-vexed question as to just how rational man is has little relevance in this vision. (Sowell, 2007, p. 18).

\footnotetext{
2 Sowell (2007), p. 33.

3 We use Friedman as an example to demonstrate that the statement is often said for neoclassical economics, the Austrian school of economics, and prominent figures of both.
} 
We begin our discussion on rationality with the context that Sowell has provided.

\section{II}

HUMAN RATIONALITY:

\section{DEFINITIONS AND MISUNDERSTANDINGS}

Sowell's categorization can get us into trouble if we are not careful, but it can also offer some elements to go further into the discussion. In fact, behind the Utopian and Tragic Visions described by the authors, we can find a more general belief about human rationality. And the way in which we answer the question «are humans rational?» manifests even more general perspectives on humanity, freedom and political control. What we will try to do is to develop a different answer to the question above - an answer, rooted in the Mises-Rothbard-Huerta de Soto tradition, that allows us to go beyond the utopian/tragic conflict, in order to categorize less but understand more.

The question as to whether humans behave rationally and to what extent has been a topic of high controversy between the various human behavioral sciences for decades. As of recent years two intellectuals in particular, Richard $\mathrm{H}$. Thaler and Cass R. Sunstein, have gained a great deal of attention from legislators and the academic community by arguing that since humans do not always behave rationally, both the private and public sectors can act as choice architects and «nudge» individuals toward choices with more favorable outcomes without restricting human freedom. They label this approach by coining the term «libertarian paternalism». Additionally, psychologist and winner of the Nobel Prize in Economics Daniel Kahneman has argued that humans are «not well described by the rational-agent model» and therefore supports libertarian paternalism as introduced by Thaler and Sunstein (2011, p. 411).

In this paper we present our defense of liberty against a decadesold debate concerning human rationality. Beyond this we ask the questions, "If humans do not behave rationally should that determine the role of government? If so, to what extent?». Our paper 
is of important timing due to a number of publications of the past few years within the human behavioral sciences. We discuss two New York Times Bestsellers in particular. Although we strongly disagree what these two books suggest for the role of government, we point out that they are still excellent sources for understanding human behavior. And lastly, we also cite several other works throughout this paper in order to enrich the context of the intellectual debate. It is important to point out that although some authors may agree with Thaler, Sunstein and Kahneman that humans do not always behave rationally, this does not mean that they necessarily agree with Thaler, Sunstein and Kahneman about the proper role of government. For this reason, it must be said that our critiques are only directed toward some of the arguments from the three authors we named here.

The first book is Nudge: Improving Decisions About Health, Wealth, and Happiness, a behavioral economics book - initially printed in 2008 and coauthored by Richard H. Thaler and Cass R. Sunstein - expands on a concept that the authors call «libertarian paternalism," which was first coined by the same authors in a 2003 article printed in The American Economic Review.

Libertarian paternalism holds that it is possible «to steer people's choices [for both the public and private sector] in directions that will improve their lives [...] as judged by themselves». ${ }^{4}$ This is done through the concept of choice architecture, which borrows from human behavioral sciences to present choices in certain ways that would make it more likely for the choice architect (the person(s) presenting the choices) to influence the choice of a decision-maker in one direction or another. In choice architecture, softly steering choices is referred to as "nudging.»

We must mention here that it is only toward usage of choice architecture in the public sector that we offer any critique. In the private sector, exchanges occur voluntarily because both buyers and sellers believe they are better off by making exchanges in the first place. If they do not like choices offered, they can go elsewhere for other options. In the public sector, by contrast, limited (forced) options are presented to taxpayers, paid for by involuntary taxation.

4 Thaler and Sunstein (2008), p. 5. 
Acts of civil disobedience (for refusing to pay) are strictly punished by violence or threats of violence. We also refute the claim that it is possible to be both libertarian and paternalistic at the same time. In Nudge, Thaler and Sunstein $(2008$, p. 5) claim that libertarian paternalism is «liberty preserving». In reality, however, liberty means «free," and paternal means "of or pertaining to a father.» Our second refutation is that governments can maintain the proper role of preserving liberty and justice while doing much of the nudging that Thaler and Sunstein propose.

The second book which we bring to the table for debate is Thinking Fast and Slow, a cognitive psychology book by Daniel Kahneman. The book was built upon an entire career of working with his collaborator Amos Tversky. It has deservingly received a great deal of praise by many, including two economists generally associated with free markets: William Easterly and David Friedman, of the Chicago school and son of Milton Friedman. On Friedman's website and blog he posts drafts for the upcoming third edition of his book The Machinery of Freedom. He writes, «The best, and most interesting, challenge to rationality that I have seen is Thinking Fast and Slow by Daniel Kahneman, a psychologist who won a Nobel prize in economics and, in my opinion, deserved it». ${ }^{5}$

To claim that Kahneman argues that humans are irrational actors would be too simplistic. It does seem that he tries to go to great effort throughout the book to demonstrate that humans are irrational actors. But in the conclusion he adds some perspective:

I often cringe when my work with Amos is credited with demonstrating that human choices are irrational, when in fact our research only showed that Humans are not well described by the rational-agent model.

Although Humans are not irrational, they often need help to make more accurate judgments and better decisions, and in some cases policies and institutions can provide that help. (Kahneman, 2011, p. 411).

To Kahneman (2011, p. 412), this provides the justification needed for governments to maintain a soft but evident paternal

\footnotetext{
${ }^{5}$ Friedman (2011).
} 
role in the lives of citizens. The book's conclusion also offers praise for Thaler and Sunstein and calls Nudge «the bible of behavioral economics.» He also frames Milton Friedman as a sort of poster child for the side of the intellectual debate that argues that humans should be free to make their own choices because they behave rationally. Kahneman cites Friedman's book Free to Choose in support of his claim.

In international relations, like in economics, students are taught the rational model of decision making. This model holds that all levels of decision-makers make decisions rationally weighing options, calculating risks and competing interests, and eventually choosing the best option (or at least the least bad option) among the choices available. This model can be used as lens for observing, interpreting and predicting behavior at all levels: the individual level, domestic (or state) level, interstate (international) level, and global level. ${ }^{6}$ Under this framework, the seemingly irrational behavior of an authoritarian figure like Kim Jong-un or of a nation like North Korea can be understood and often predicted when the major incentives and punishments are known by the observer. Within this framework it could also be argued that even heroin use is rational behavior - not because its effects on the human body are «not so bad» but because the user merely prefers the short-term pleasure over long-term health. The behavior is rationalized in the user's mind. Especially if the user had already developed an addiction, an observer with understanding of the rational model would not be shocked to see the user using again. Many in related fields of academia would claim that, at least according to the rational model of decision making, the logic follows.

In the field of economics the equivalent model is referred to as «rational choice theory». In fact, the drug use example was argued by two professors of the Chicago School of Economics, Kevin M. Murphy and Gary Becker, and Kahneman makes note of this in his book. In 1988, Murphy and Becker (1988, p. 675) coauthored a paper called $A$ Theory of Rational Addiction. In this

${ }^{6}$ Goldstein and Whitworth (2005), p. 85. 
paper, «rational» is defined as «a consistent plan to maximize utility over time». By this definition, individuals can make decisions for short-term gains with harmful and even fatal longterm consequences and still be considered to behave rationally.

Daniel Kahneman points out his problem with this definition:

The only test of rationality is not whether a person's beliefs and preferences are reasonable, but whether they are internally consistent. A rational person can believe in ghosts so long as all her other beliefs are consistent with the existence of ghosts. A rational person can prefer being hated over being loved, so long as his preferences are consistent. Rationality is a logical coherencereasonable or not. (Kahneman, 2011, p. 411).

In the traditional sense of the word rational refers to «showing clear thought or reason». Reason, unlike intuition, requires an active cognitive process of fact verification and use of logic. One common critique of rationality is that humans are highly susceptible to the framing technique. That is, the same information can be presented in different ways, but supposedly rational humans make different choices depending on how information is presented. One example from Kahneman's book is as follows:

A patient is fatally ill but could survive by undergoing a surgery. A doctor can likely influence the patient to undergo the surgery by stating the she has a ninety percent chance of survival with the surgery. Similarly, the doctor could frame the circumstance in a different light by stating that there is a ten percent chance that the surgery will be fatal. The information is said to be the same; however, the "supposedly rational» patient may make a different decision based on how the information is presented. ${ }^{7}$

The logic seems sound, and there is something to be said about framing and rationality. Nonetheless, Pinker's book The Stuff of Thought: Language as a Window into Human Nature provides a counter-argument stating that just because humans can be persuaded one way or another with the technique that this is

7 Kahneman (2011), p. 88. 
not necessarily irrational. Different ways of framing a situation may be equally consistent with the facts being described in that very sentence, but they make different commitments about other facts which are not being described... To take the most obvious example, taxes and membership fees are not two ways of framing the same thing: if you choose not to pay a membership fee, the organization will cease to provide you with its services, but if you choose not to pay taxes, men with guns will put you in jail... Debaters who frame an event in these two ways are making competing predictions about unobserved facts, just like scientists who examine the same data and advance competing theories that can be distinguished by new empirical tests. (Pinker, 2007, p. 260).

In evolutionary psychology, «rational» action in terms of utility maximization (in the same sense that economics generally refers to utility maximization) is far too simplistic. In Gad Saad's book The Consuming Instinct: What Juicy Burgers, Ferraris, Pornography, and Gift Giving Reveal about Human Nature, the author argues that rational choices are made through four overriding Darwinian pursuits: survival, reproduction, kin selection, and reciprocity.

[D]eep rationality proposes that individuals apply decision rules that would have maximized their fitness (capacity to propagate one's genes) when tackling adaptive challenges in specific domains (e.g., mate search, kin protection, predator avoidance, maintenance of status). In this sense, the metric of rationality should be defined according to an understanding of our ancestors' «deep evolutionary time» (i.e., our evolutionary history). (Saad, 2011, p. 269).

In The Virtue of Selfishness - a collection of essays published in 1964 - Ayn Rand and Nathaniel Branden present the objectivist view of reason and rationality. According to Rand, objectivism holds that reason is the basic means of survival. She does not argue that man behaves rational in every instance, but rather, that he has the choice to behave rationally and that doing so is essential to his survival. Quoting John Galt's speech from Atlas Shrugged she writes 
Man has been called a rational being, but rationality is a matter of choice-and the alternative his nature offers him is: rational being or suicidal animal. Man has to be man-by choice; he has to hold his life as a value-by choice; he has to learn to sustain it by choice... (Rand, 1964, p. 23).

In a later chapter, Branden writes that

An individualist is, first and foremost, a man of reason. It is upon the ability to think, upon his rational faculty, that man's life depends; rationality is the precondition of independence and self-reliance. (Rand, 1964, p. 136).

To demonstrate just how much the concepts of rationality differ so drastically, we will compare here the objectivist concept of rationality to that of evolutionary psychology. Rationality, as Rand and Branden define it, means using clear thought and reason to take certain actions necessary for one's survival. While their definition concentrates on the survival of the individual, evolutionary psychology brings it a step further in that rational actions are those that are taken for the survival of one's genes. This expands the concept of rationality beyond one's self to one's offspring and kin, since after all, relatives share a percentage of the genes. Beyond this, evolutionary history must be used as a lens for understanding behavior.

Kahneman (2003, p. 698) explains how the brain works through dual process theory. The theory holds that the brain processes information through two basic systems. These systems are labeled «System 1» and «System 2». System 1, known as the intuition or automatic system is fast, parallel, automatic, effortless, associative, slow-learning, and emotional. It is well-suited to answer questions such as the product of $2 \times 2$ but not $17 \times 24$. System $2-$ known as the reasoning system - is, by contrast, slow, serial, controlled, effortful, rule-governed, flexible, and neutral. For most people, System 2 is needed to find the answer to more complicated questions, such as the product of $17 \times 24{ }^{8}$

8 Kahneman (2011), p. 23. 
In Nudge, Thaler and Sunstein expand upon dual process theory and coin two terms: Humans and Econs. Humans, according to the framework they propose, predictably err. The example given in the book is the "planning fallacy» in which Humans should be able to predict that a contractor would likely fail to meet deadlines, as most seem to do. Humans seem to fail to consider all the options when presented to them, are susceptible to the framing effect, are unable to make complex calculations effortlessly, and are impulsive in decision-making. Econs, by contrast, «are not required to make perfect forecasts [...] but are required to make unbiased forecasts. That is, the forecasts can be wrong, but they can't be systematically wrong in a predictable direction $» .{ }^{9}$ Econs are not susceptible to the framing effect, are able to make complex calculations effortlessly, and are not impulsive.

Thaler and Sunstein argue that since actual human beings are hardly the rational actors that Econs are, choices can be presented to Humans in a way that will nudge them in the right direction. They suggest that this can be done through a concept that they call «choice architecture.» Under choice architecture, the person presenting choices (or choice architect) to the chooser, while knowing which choices would most benefit most individuals, can follow certain guidelines to «nudge» those individuals toward certain directions. The acronym «NUDGES» is used: Incentives, Understanding mappings, Defaults, Give feedback, Expect error, Structure complex choices.

Our argument is that choice architecture is an excellent concept when used in the private sector. One good example proposed by the authors goes as follows: The choice architects of gas pumps (engineers, in this case) for "pay at the pump» gas stations can design the pumps to accept credit cards no matter which way the consumer puts the credit card into the machine. Since not every consumer consistently follows directions in the image on the pump showing the correct way to insert the card, consumers can benefit from well-designed choice architecture, and no freedom

\footnotetext{
9 Thaler and Sunstein (2008), p. 7.
} 
is restricted. This would be one such implementation of the «Expect error» aspect of the «NUDGES» acronym. We argue that (this being a private sector solution) is a great concept and is consistent with libertarian values, assuming that the designing of the gas pump is done by a private company with no taxpayer money.

One more such example of choice architecture proposed by Thaler and Sunstein demonstrates how defaults are used in presenting choices (the «D» in «NUDGES»). For example, in offering government healthcare benefits, the authors argue that the choice architect must understand which choices would benefit most people. The default option could be auto-enrollment in the option that most participants are likely to most benefit from, or the default could also be set to non-enrollment and require each participant to read through the benefits of each choice before choosing. We argue that this case - being government-imposed healthcare - is completely inconsistent with libertarian values. Don't get us wrong; the idea of understanding how defaults and the rest of choice architecture is great! For example, a private company offering private healthcare benefits to its employees could set the default to be auto-enrollment in the healthcare plan that most people could best benefit from - especially since most people are unlikely to read through all the paperwork detailing each plan. For the private sector, choice architecture is an excellent concept. Remember: in the private sector, individuals are truly free to choose; they can always quit working for a particular employer, for example, if they do not like benefits of the job.

It is not that the authors do not propose any libertarian solutions for the public sector at all. For example, they do propose that the government drop its monopoly on the definition of marriage. In this case the government would maintain the role of treating marriage as a contract between two free individuals, regardless of gender. Our problem with libertarian paternalism is that most ideas proposed in Nudge are within the framework of maximizing choice within government-imposed solutions. In this sense, there is nothing libertarian about libertarian paternalism. It may be a softer paternalism, but it is completely incompatible with the market economy that is so fundamental to classic liberal 
values. Thaler and Sunstein do suggest that individuals could have the freedom to opt out of certain government programs; this, in their view, makes libertarian paternalism consistent with libertarianism. And to be fair, they do argue that individuals should be free to not have to pay taxes for government programs in some cases, assuming those individuals opt out. A couple of examples include schooling (the authors promote school vouchers) and lottery tickets. Nonetheless, it seems that Thaler and Sunstein do not recognize the overwhelming tendency for governments to grow ever larger and more restrictive of individual choice - as they have always done. They also seem out of touch with government's tendency toward inefficiency and waste. And lastly, it must be mentioned again that Thaler and Sunstein (2008, p. 7) begin their argument by building on the fact that «research has raised serious questions about the rationality of many judgments and decisions that people make». Whether or not humans are rational actors is not our point here. Our point is that Thaler and Sunstein's arguments fail to recognize that governments are in a poor position to nudge individuals toward optimal choices since they are comprised by human beings of the same planet. (We discuss this in greater detail shortly).

Thaler and Sunstein (2008, p. 5) also use Milton Friedman's name to win over readers that are sympathetic to libertarian arguments. In the authors' own introduction they write: «To borrow a phrase from the late Milton Friedman, libertarian paternalists urge that people should be "free to choose"». Unfortunately, Nudge was printed two years after Milton Friedman's death, so he was, therefore, unable to point out for himself the illiberal aspects of libertarian paternalism and disassociate his ideas from that of Thaler and Sunstein.

Do Thaler and Sunstein believe in libertarian ideas and limited government? If they were offered «keys to the kingdom», would they maintain the softer paternalism, or would they force big government upon the people? The last chapter of Nudge (called «The Real Third Way») speaks for itself. Instead of abiding by their claim that they, like Milton Friedman, want individuals to be «free to choose,» they instead admit their book is an attempt to balance right-wing and left-wing politics. 
In 2009, Sunstein received a presidential appointment to the Administrator of the White House Office of Information and Regulatory Affairs - a position he held until 2012. No doubt, his intentions were to do good for society, but nonetheless, he sought to govern and to regulate. In his mind, his intellectual knowledge was far superior to the mundane knowledge of 300 million Americans.

But even before Nudge made it to print, Sunstein had already published a different book pushing hard paternalism called The Second Bill of Rights: FDR's Unfinished Revolution And Why We Need It More Than Ever. In the book he states (while partially reiterating a quote from FDR):

Freedom from fear is inextricably linked to freedom from want. Liberty and citizenship are rooted in opportunity and security. In a sense, America lives under the second bill. But in another sense, we have lost sight of it. The second bill of rights should be reclaimed in its nation of origin. (Sunstein, 2004, p. 234).

For the readers unfamiliar with the Second Bill of Rights (often referred to in politics as the Economic Bill of Rights), as proposed by FDR himself in his 1944 State of the Union Address, we quote part of it here:

The right to a useful and remunerative job in the industries or shops or farms or mines of the nation;

The right to earn enough to provide adequate food and clothing and recreation;

The right of every farmer to raise and sell his products at a return which will give him and his family a decent living;

The right of every businessman, large and small, to trade in an atmosphere of freedom from unfair competition and domination by monopolies at home or abroad;

The right of every family to a decent home;

The right to adequate medical care and the opportunity to achieve and enjoy good health;

The right to adequate protection from the economic fears of old age, sickness, accident, and unemployment;

The right to a good education. ${ }^{10}$

10 Franklin D. Roosevelt American Heritage Center. 
In sum, FDR proposed that the limited role of government be shifted from recognizing the self-evident truth that individuals had been endowed with the rights to life, liberty and pursuit of happiness to that of guaranteeing freedom from all want. Just how exactly FDR intended to pay for houses, education, healthcare, food, clothing, as well as a much expanded labor force new government departments that would be used to «protect» businessmen from competition and monopolies and deliver these protections from all want without infringing on the already established right to liberty, pursuit of happiness was not addressed in the speech. Rights were no longer self-evident, coming from God or nature. They were now self-evident, coming from something that FDR and his advisors had simply drawn up with a pen and with plans to impose them upon the American taxpayer.

To demonstrate the libertarian perspective on governmentrationed rights, we compare FDR's perspective on rights to that of Frédéric Bastiat, a $19^{\text {th }}$ Century French theorist and hero of many libertarian circles as well as Austrian economists. Here we quote Bastiat's book The Law:

The Socialists say, since the law organizes justice, why should it not organize labor, instruction, and religion?

Why? Because it could not organize labor, instruction, and religion, without disorganizing justice.

For remember, that law is force, and that consequently the domain of the law cannot properly extend beyond the domain of force.

When law and force keep a man within the bounds of justice, they impose nothing upon him but a mere negation. They only oblige him to abstain from doing harm. They violate neither his personality, his liberty, nor his property. They only guard the personality, the liberty, the property of others. They hold themselves on the defensive; they defend the equal right of all. They fulfill a mission whose harmlessness is evident, whose utility is palpable, and whose legitimacy is not to be disputed. This is so true that, as a friend of mine once remarked to me, to say that the aim of the law is to cause justice to reign, is to use an expression that is not rigorously exact. It ought to be said, the aim of the law is to prevent injustice from reigning. In fact, it is not justice 
that has an existence of its own, it is injustice. The one results from the absence of the other.

But when the law, through the medium of its necessary agentforce-imposes a form of labor, a method or a subject of instruction, a creed, or a worship, it is no longer negative; it acts positively upon men. It substitutes the will of the legislator for their own will, the initiative of the legislator for their own initiative. They have no need to consult, to compare, or to foresee; the law does all that for them. The intellect is for them a useless encumbrance; they cease to be men; they lose their personality, their liberty, their property. (Bastiat, 2007, p. 64).

During the Enlightenment period, John Locke's Second Treatise of Civil Government described natural rights as life, liberty, estate (meaning property). Thomas Jefferson borrowed from Locke and described them as life, liberty, pursuit of happiness in the Declaration of Independence. Bastiat (who lived after Enlightenment philosophers) described these as individuality or personality, liberty and property. While neither Locke nor Jefferson fully practiced what they preached - Locke gave provisions for slavery in the Fundamental Constitutions of Carolina in Articles 107 and 110; Jefferson had slaves himself - their words provided the intellectual arguments that were later finally recognized by governments around the world. Pinker has made similar arguments:

[T]hough [Locke] and many of his intellectual descendants hypocritically profited from the institution [of slavery], their advocacy of liberty, equality, and the universal rights of man let a genie out of the bottle and made it increasingly awkward for anyone to justify the practice. (Pinker, 2011, p. 155).

For those that have a hard time accepting the concept of natural rights, consider the opposite. To say that you do not have the right to life is to say that others may to take it whenever it suits them. To say that you do not have the right to liberty is to say that others have the right to make you a slave. Do others have the right to steal your home, car or other property? Do others have the right to restrict your pursuit of your own values when 
those pursuits are harmless to all others? If you can come to the conclusion that the answer to these questions is «no,» then the next question is: "What makes you so special?». If others have no right to infringe on your natural rights, what gives you the right to do so to others?

It is through the recognition of the self-evident truths proposed during Enlightenment that many libertarians (or classic liberals) derive their arguments for both liberty and equality. ${ }^{11}$ While socialism seeks to use government to ensure equality of outcome, libertarian values (free markets being among the most fundamental of these) seek equality through liberty. They recognize that «Jefferson made it clear that he was referring to an equality of rights, not a biological sameness.» ${ }^{12}$

The problem with adding material rights (beyond the right to accumulate property by voluntary exchange) and collective rights is that they come at the expense of the natural rights of individuals. Take the UN's Millennium Development Goals, for example: the eradication of poverty and hunger, universal education, gender equality, child health, maternal health, combat HIV / AIDS, environmental sustainability, and global partnership. The Goals began in 2000 and are hoped to be achieved by 2015. Among the proponents are a number of world renowned celebrities, actors and actresses, athletes, and even a princess. U2's Bono and «rock star economist» Jeffrey Sachs, a Colombia University professor, are just two individuals that have received a great deal of attention for their support.

So once natural rights are established, what can be said for planning? No discussion of the role of government and central planning would be complete without a discussion of knowledge itself. Sowell (2007, p. 13) distinguishes between intellectual and mundane knowledge in his book Intellectuals and Society. He rebukes intellectuals for thinking that they can somehow do more

11 Many libertarians (Mises, for example) come to similar conclusions on strictly utilitarian grounds. It is also important to point out here that some would argue that natural rights were articulated by Jesuits of the School of Salamanca long before the Enlightenment thinkers.

12 Pinker (2002), p. 145. 
good than harm for society by means of centralized planning. All the intellectual knowledge needed to understand the complexities of the sea or the engineering required for shipbuilding could not have prevented the sinking of the Titanic. It was the mundane knowledge "of where particular icebergs happened to be located on a particular night» that was needed.

So are humans rational? The answer to that question is beyond the scope of this paper. But we first point out that the answer must depend upon how the word is defined. As we have demonstrated already, various academic disciplines define the word in different ways. To confuse the matter more, prominent intellectuals within those disciplines do not even entirely agree on single definitions within their respective fields. Our stance (as it pertains to the role of government) is as follows: Who cares?

The various human behavioral sciences have (in our minds) brought forth some new interesting questions about rational choice theory. It should be agreed upon that homo economicus is not the best way to describe homo sapiens. ${ }^{13}$ Humans waste money and other resources in order to not have to admit that sunk costs are sunk costs. Humans are easily suckered by the framing effect. These are fair points. So let us make clear once again that we only wish to challenge Thaler, Sunstein and Kahneman's suggestion for what human irrationality should mean for the role of government.

Let us review the logic as proposed by Thaler, Sunstein and Kahneman as it pertains to the role of government:

1. Humans behave irrationally and sometimes make poor choices as a result.

2. Governments can help individuals make better choices.

But we must point out that Thaler, Sunstein and Kahneman have forgotten or ignored an important factor, which we address in point two below. Points three and four follow naturally as a result of point two being true.

13 Mises (2008), p. 62. 
1. Humans behave irrationally and sometimes make poor choices as a result.

2. Governments are run by irrationally-behaving humans.

3. Therefore governments behave irrationally.

4. Irrationally-behaving governments are in a poor position to help individuals make better choices.

Are we really to believe that governments behave so much more rationally than humans do? Do the choices of governments not reflect short-sighted agendas due to election cycles and administration changes, party politics, competing interest groups, bureaucracy, and a whole host of other factors, making them all the more irrational?

If rational means having access to unlimited information about choices and being able to conduct perfect and exact advanced computations about the benefits and consequences of each and consistently choosing options that result in the best long-term gains, then by that definition, we are not rational beings. (To use Thaler and Sunstein's terminology, we Humans are not Econs). But to say that irrational humans need to be saved by irrational governments is a poor argument, and its intellectual framework is dangerous because it only serves to legitimize weakminded legislators in search of scientific backing for their political agendas.

When it comes to freedom (as in the right to self-determinism), we are less concerned with whether or not humans always behave rationally. We argue that a more important concept to understand is purposeful action. We also point out that only for simplification we have referred to government behavior and action. But it must be said that governments do not behave or act at all. Only the individuals that comprise them behave and act. Such is the topic of praxeology - the logic of human action, which we explain in the next section.

To conclude this section briefly, we reiterate Bastiat's argument, when government operates outside the boundaries of protecting justice, justice itself is sacrificed. Life, liberty, property are sacrificed. The integrity of the mind of man is sacrificed. If man is irrational, then allowing other irrational men to do his thinking 
for him by using government is certain to make him all the more irrational.

\section{III \\ RATIONALITY VS. PURPOSEFUL BEHAVIOUR: THE (NON) ROLE FOR GOVERNMENT}

We would like to move beyond the concept of rationality described so far, in order to follow a definition that, according to us, is more suitable with the very nature of human behavior. In fact, the word «rationality» has become very ambiguous over time, often confused with the possibility to measure mathematical quantities without error. In economics, moreover, rationality seems to mean to some that humans have a sort of omniscience, able to drive to perfect forecasts about the future course of events. ${ }^{14}$ In this sense, «rationality» is a word we prefer to disregard for now.

In this regard, Hayek's acceptance speech for the Nobel Prize in 1974 is memorable. ${ }^{15}$ Taking up a number of crucial considerations expressed in Hayek (1964), Hayek (2008, p. 30) associates the persistent errors of economists with «their propensity to imitate as closely as possible the procedures of the brilliantly successful physical sciences». Economists, with the pretext of being «scientists», imitate the methods of the natural sciences but in doing so apply an inappropriate method to the study of human sciences, giving birth to utterly unscientific theories, since the method is not imposed by the object studied in accordance with the Aristotelian tradition but by the ideological preconceptions of the scholars themselves.

Therefore, considering the very nature of human action, as in Ferlito (2013), and following Mises (1998, p. 11), we can define human action as «purposeful behavior.» This definition of human action is the foundation for the praxeological method founded

14 To be fair to Thaler and Sunstein, they make clear that they do not assume omniscience even for Econs. To our knowledge, Kahneman does not assume this either.

15 Hayek (2008). 
by Ludwig von Mises and followed by important members of the Austrian School, such as Murray N. Rothbard and J. Huerta de Soto.

Or we may say: Action is will put into operation and transformed into an agency, is aiming at ends and goals, is the ego's meaningful response to stimuli and to the conditions of its environment, is a person's conscious adjustment to the state of the universe that determines his life. (Mises, 1998, p. 11).

Ends and means therefore are the given human action implemented through plans that take shape and are realized over time. As we can immediately understand, such a definition is much stronger than the concept of rationality. In fact, while the concept of rationality is quite controversial and seems to imply the idea of «success», "coordination», or "perfect outcome», purposefulness seems to be a more undeniable feature of human behavior. All human action is, without a doubt, set in motion to reach goals. Purposeful action, moreover, can be seen as the link between preferences and expectations, stressed by Lachmann. Preferences generate expectations and the bridge between them is in the action, accomplished over time. From this simple truth the Austrian School of Economics derives more general observations of human action.

First of all, it must be said that individuals prefer to achieve goals in the shortest time possible, ceteris paribus. This consideration leads us to a category closely related to that of capital in the Austrian theoretical tradition: the law of time preference, i.e., at par circumstances, present goods are preferred to future assets. ${ }^{16}$ That is, faced with two objectives of equal value, the player prefers the one which can be achieved more rapidly. ${ }^{17}$ However, any discussion of time requires a clarification as to which concept is consistent with our perspective. Following $\mathrm{O}^{\prime}$ Driscoll and Rizzo (2002), we will explain the importance of differentiating

16 Concept introduced by Böhm-Bawerk in the $19^{\text {th }}$ Century. See Schulak and Unterköfler (2011), p. 34.

17 Huerta de Soto (2010a), pp. 45-46. 
real time from Newtonian time and link first to the inevitable ignorance that characterizes the process of human action.

Dominant economic theory, especially of the neo-classical kind, uses the historic series and the Cartesian plane as tools for representing its results. It consequently seems to give importance to time. However, such a perception of time, while perhaps being useful in the study of physical sciences, is rather unsuitable for the discovery and surprise dynamics typical of human action. It is what we may define as Newtonian time.

The Newtonian conception of time is spatialized; that is, its passage is represented or symbolized by «movements» along a line. Different dates are then portrayed as a succession of line segments (discrete time) or points (continuous time). In either case, time is fully analogized to space, and what is true of the latter becomes true of the former. (O'Driscoll and Rizzo, 2002, p. 82).

O'Driscoll and Rizzo (2002, pp. 82-85) emphasise that time conceived in this way has three main characteristics: homogeneity, mathematical continuity and causal inertia. Homogeneity means that different temporal moments are simply points in space, a temporal position; nothing may happen between one moment and another. This means that homogeneous time is fundamentally static. Mathematical continuity, on the other hand, implies that time is simply a sequence of moments, which may even be different, but no change can take place endogenously. Since time is a sequence of static situations, each change must be exogenous. Causal inertia, lastly, means that nothing happens with the flow of time. There is no learning; there is no change in knowledge or adjustment of expectations. The system itself must already contain all the elements needed for it to function. It is evident that while such a concept may fit the description of physical phenomena, where actions are always met by the same reactions, it lends itself poorly to representing unpredictable and dynamic human actions.

What interests us, on the other hand, is real time, a «dynamically continuous flow of novel experiences. [...] We cannot experience the passage of time except as a flow: something new must 
happen, or real time will cease to be». ${ }^{18}$ As described by O'Driscoll and Rizzo (2002, pp. 89-91), the characteristics of real time are precisely opposite to those of Newtonian time. They are: dynamic continuity, heterogeneity and causal efficacy. If we consider dynamic continuity, time must consist of memory and expectations; i.e. it is structurally related moments, past and future, through the perceptions of the individual; one cannot imagine a present without memory of the past and expectations for the future; inasmuch, all the moments in the flow of time are intimately linked and reciprocally influenced. Heterogeneity, on the other hand, means that in each successive moment the individual's perception has of the facts may be, and in fact is, different: the past, once it has occurred, becomes memory, enhancing the present and thereby also changing perception of the future; therefore, the perception of things changes from moment to moment, thereby making the characteristics of a given moment in time radically different from those of the previous moment. The direct consequence of heterogeneity is causal efficacy; the flow of time modifies knowledge, awareness and information, thereby expanding the creative potential of human action. Yet this is possible precisely because of acquisitions made «beforehand» in time.

Given what we have outlined, it will be evident that uncertainty ${ }^{19}$ is one of the key elements in human action. On a closer look, we cannot even imagine that opportunities for profit will arise outside a context of uncertainty and disequilibrium. ${ }^{20} \mathrm{In}$ fact, without uncertainty, all occasions for profit would have already been exhausted; in an uncertain context, on the other hand, entrepreneurs who make the best forecasts or people who, for various reasons, best fulfill their expectations and plans, enjoy an advantage created precisely by the fact of knowing better how to move in such a context, how to «imagine the future better».

Once again, as for time, reference must be made to a «true» concept of uncertainty and not to a formal stylization. The main features of true uncertainty «are the inherent unlistability of all

18 O'Driscoll and Rizzo (2002), p. 89.

19 See in particular O'Driscoll and Rizzo (2002), chapter 5.

20 Rizzo (1979b), p. 10. 
possible outcomes resulting from a course of action, and the complete endogeneity of the uncertainty». ${ }^{21}$ Inasmuch, if uncertainty is endogenous to the system, an intrinsic feature, it cannot but originate a constantly changing system.

In such a system, it is evident that even the acquisition of new information cannot eliminate uncertainty. The accumulation of knowledge merely changes the uncertainty. ${ }^{22}$ The information content is not complete, only larger. Aspects affecting the pursuit of action have changed but are not complete. The outlines on the horizon, and consequently the uncertainty in relation to the complete form, are different.

Such a vision is challenging the concept of rationality as it is mainly intended by economic theory, a concept according to which there is no room for general errors and that it is strictly related with the neoclassical view on general economic equilibrium. Equilibrium and rationality in neoclassical theory are absolutely incompatible with the concepts of real time and the mutability of knowledge. In fact, Walrasian equilibrium is incompatible with the real world. However, this does not mean that we must completely abandon every attempt to define certain situations of equilibrium in the system. In accordance with the Austrian tradition, the concept of equilibrium lies in the coordination of the plans of individual players on the market. In this sense, equilibrium can be allowed, but not in the sense that it enables «Pareto optimums» ${ }^{23}$ or perfect coordination. ${ }^{24}$ The equilibrium may not exist as a point but as a process. What we have in mind is a situation in which individuals are effectively free to act and relate with each other; their knowledge is molded and modified through interaction, allowing the system as a whole to be understood better but not totally. This process of discovery, in an effort towards coordination and discovery, stimulates a constant tension towards balance. An equilibrium that, as a destination, does not exist or at least is constantly changing. Yet it exists as a procedural

21 O'Driscoll and Rizzo (2002), p. 100.

22 O’Driscoll and Rizzo (2002), pp. 102-103.

${ }^{23}$ Not even imagined by Pareto himself.

24 O’Driscoll and Rizzo (2002), pp. 117-118. 
dynamics. The free coordination of plans is not a destination but a journey. In any case,

there is nothing that requires a useful equilibrium idea to function as a center of gravitation in respect to each and every movement in disequilibrium. It is sufficient that there be movements in a equilibrating [sic] direction often enough to make the toil and trouble of equilibrium construction worthwhile. Obviously this is a matter of scientific judgment, rather of scientific precision. (Rizzo, 2002, pp. 186-187).

Equilibrium, therefore and in accordance with our vision, does not involve achieving a condition of static optimality but, rather, a dynamic situation in which market players are free to act in seeking fulfilment of their plans. The equilibrium lies in the true possibility for these agents to enact the dynamic process needed to implement their plans: definition of purposes, search for means, intertemporal coordination in interaction with other subjects, discovery of new information, redefinition of plans, etc. Our idea is very close to the one expressed by Rizzo (2002).

In regards to the definition of the action process in a climate of uncertainty, and the subsequent definition of a state of dynamic equilibrium in the sense defined above, ${ }^{25}$ the key element is the concept of expectations: the desires for the future and scenarios that we expect will occur determine our possibilities for action. The evolution of the concept of preferences towards the concept of expectations can be considered as one of the major innovations produced by methodological subjectivism in the last century. ${ }^{26}$ And it is a perfect instrument for our analysis. If human action is basically shaped by the concept of «purpose,» of course purposes are in themselves shaped by expectations.

It is evident that expectations cannot be considered, as in neoclassical theory, as a static element fixed at the beginning of the match and then unchangeable until the final result is achieved. tations.

25 As a never-ending process of action pursuing the satisfaction of personal expec-

26 Lachmann (1979), p. 65. 
On the contrary, since human action is a dynamic process that unfolds over time, the set of information available to players constantly changes, bringing about a continual modification of expectations, objectives and plans.

The economist who most deeply analyzed the concept of expectations, re-interpreting them dynamically and inserting them in the Austrian theoretical paradigm, was Ludwig M. Lachmann, a German author who, in the sphere of our most recent thinking, is proving to have a decisive influence. His early works from the 1930s and 1940s helped develop the Austrian theory of capital and the business cycle theory. However, his opera magna, Capital and Its Structure, ${ }^{27}$ published in 1956, sought to include the concept of uncertainty and expectations firmly in the Austrian theory.

Acknowledging Keynes's important function in having introduced the concept of expectations in an organic way with A Treatise on Money (1930), and referring Shackle's contribution, ${ }^{28}$ an «Austrian» turned partially Keynesian, ${ }^{29}$ Lachmann sought to engage his own contribution completely within the Austrian tradition, albeit with the necessary distinctions. In particular, he felt that the Austrians missed the opportunity to insert expectations within their own thinking in an organic way.

It is a curious fact that, when around 1930 (in Keynes's Treatise on Money) expectations made their appearance in the economic thought of the Anglo-Saxon world, the Austrians failed to grasp with both hands this golden opportunity to enlarge the basis of their approach and, by and large, treated the subject rather gingerly. (Lachmann, 1976a, p. 58).

27 Lachmann (1978).

28 George Lennox Sharman Shackle (1903-1992) was born in Cambridge and is therefore British. Our definition of him as «Austrian» refers to his scientific approach. He earned his Ph.D. at the London School of Economics in the 1930s under the guidance of Hayek.

29 As told by Rothbard, Lachmann was fond of saying: «When I arrived in London in the early 1930s, it was safe to say that everyone at the London School of Economics was an Austrian. After the war, however, Hayek and I were the only Austrians left». 
Lachmann embraces Shackle's concept of the kaleidic socie$t y,{ }^{30}$ "a society in which sooner or later unexpected change is bound to upset existing patterns, a society "interspersing its moments or intervals of order, assurance and beauty with sudden disintegration and a cascade into a new pattern" $» .{ }^{31}$ In contrast, for Hayek, the definition of a dynamic balance, based on the coordination of plans, in any case requires a certain closeness to a situation of general economic equilibrium. ${ }^{32}$

Expectations are consequently the hallmark of a society made of real players which, starting precisely from them, form their own plans for the future, meeting and modifying knowledge and the plans themselves. This generates the kaleidoscopic world, a world where change is constant. In a kaleidoscopic society, moreover,

the equilibrating forces, operating slowly, especially where much of the capital equipment is durable and specific, are always overtaken by unexpected change before they have done their work, and the results of their operation disrupted before they can bear fruit. [...] Equilibrium of the economic system as a whole will thus never be reached. (Lachmann, 1976a, pp. 60-61).

Expectations, by generating plans, generate purposeful human action that is the necessary for economic processes. ${ }^{33}$ As time progresses, expectations change during the process. With the accumulation of knowledge, the scenario is constantly changing. In our view, it is precisely - provided it is free - in the harmonic process of continuous adaptation of plans and expectations that our conception of equilibrium lies. Yet, bear in mind, that expectations are not something «up in the clouds»; without them, there is no economic activity at all; it is starting from expectations that every decision is taken with the intention of making a profit or achieving personal satisfaction. However, these attempts emerge in a context of imperfect knowledge and an unexpected

\footnotetext{
30 See Shackle (2009), pp. 76-79.

31 Lachmann (1976a), p. 54.

32 Rizzo (2002), p. 184.

33 As Hicks (2002), p. 284 said, «production will not be undertaken unless expectations are formed».
} 
and unpredictable future. ${ }^{34}$ And, again, dynamic equilibrium does not lie in the coherence of expectations but rather in the individual process which each agent enacts in the attempt to achieve them.

It may seem that we have probably gone too far in our analysis. But this is not the case. Just to make perfectly clear: we have given up the concept of human rationality because it is ambiguous and a source of misunderstanding in psychological and economic analysis. We prefer to define human action as marked by purposefulness, which, put another way, means human beings always act in order to achieve something. In doing so they are guided by their expectations. And, finally, expectations are the driving force for both plans and actions.

We make no claims that only neoclassical economists have built arguments upon the belief that humans are rational. Ludwig von Mises himself argued the following:

Human action is always rational... The ultimate end of action is always the satisfaction of some desires of the acting man. Since nobody is in a position to substitute his own value judgments for those of the acting individual, it is vain to pass judgment on other people's aims and violations. No man is qualified to declare what would make another man happier or less discontented. (Mises, 2008, p. 18).

So Kahneman was right when he wrote that the meaning of rationality in the field of economics is "not whether a person's beliefs and preferences are reasonable, but whether they are internally consistent» (2011, p. 411). A rational person could indeed believe in ghosts as long as other beliefs reflect consistency in this belief. Do humans always reach the optimum? In a way we can answer «yes». But only if we consider this optimum objectively limited by limited and changing information. In other words, given the content of information that they have, humans behave consistently with their ever-changing plans. This of course means that humans cannot pursue all their goals at the same time. Choice is at the core of the action process.

34 See Lachmann (2002). 
The acting person therefore has to identify to the best of his abilities the alternative that, under the given circumstances, is for him the most important one.

This identification process is future-oriented and, therefore, heavily speculative. [...]

Now, subjectively - that is, as far as the mere opinion of the acting person is concerned - he always chooses the most important project. By the very fact that he acts in this manner rather than another, he «demonstrates» his belief that this action is better than any other he could have performed instead. Ex ante, then, his choice is always optimal. (Hülsmann, 2000, p. 4).

It is only ex post that is possible to judge whether or not we had better alternatives. But, at the very moment of the choice, the chosen alternative was the best, consistently with the content of knowledge at our disposal.

From our perspective, thus, government control is not conceivable on the basis that humans are not rational, and we explain why. The argument for government intervention over «human irrationality» is based on, as we stated above, the academic attempt to treat economics and human action sciences as physical sciences. Government planning and intervention, in fact, is based on the erroneous notion that governments can be rational while humans are not. So, how is it then that the central planner is more rational than all others, and how is it then that the central planner has more perfect information at his disposal?

It is now necessary to compare our idea of human action with the specular one for government control, one that we generally define as socialism. Following Huerta de Soto (2010b, p. 3), we define socialism as «any system of institutional aggression on the free exercise of human action or entrepreneurship». It is evident, therefore, that our definition is much broader than generally is intended. If the essence of economic theory is the study of human action (as above defined), and if «the core, or most characteristic feature of human nature is the ability of all people to act freely and creatively», 35 there is evidently no point in identifying nuances

35 Huerta de Soto (2010b), p. 3. 
in regards to the degree of aggression that State action may have in relation to free human action. These considerations are based on an authentic conception of man and entrepreneurship.

In a broad or general sense, entrepreneurship actually coincides with human action. In this respect, it could be said that any person who acts to modify the present and achieve his objectives in the future exercises entrepreneurship. Although at first glance this definition may appear to be too broad and to disagree with current linguistic uses, let us bear in mind that it coincides with a conception of entrepreneurship which economists are increasingly studying and developing. Moreover, this conception fully agrees with the original etymological meaning of the term «enterprise.» (Huerta de Soto, 2010b, p. 15).

All subjects, in performing the entrepreneurial function ${ }^{36}$ defined in this way, set themselves objectives and purposes dictated by their expectations. Having defined the objectives, the means for achieving them must be chosen in a process that unfolds over time. The attainment of certain objectives naturally involves costs, arising from the subjective perception of renouncing the attainment of other goals. The expectation is that the subjective benefit obtained on attaining the objective is higher than cost/ sacrifice. The concept of entrepreneurial profit lies in this difference. ${ }^{37}$ This does not mean that losses may not be incurred or entrepreneurial errors be made. That is, over time, entrepreneurs may realize that errors were made in the choice of means and purposes and that these entrepreneurial activities must therefore be reviewed. ${ }^{38}$ This is possible precisely because, through the free exercise of human action, discovering the error increases the heritage of information. The nature of economic calculation lies in this comparison between entrepreneurial gains and losses. In a market regime, such assessments are possible because subjective assessments, in terms of income and sacrifice, are transformed into

${ }^{36}$ For in-depth analysis of the concept of entrepreneurship, see Huerta de Soto (2010b), pp. 15-48.

37 Huerta de Soto (2010b), pp. 17-18.

38 Huerta de Soto (2010b), p. 18. 
objective values through the price mechanism. It precisely mirrors the subjective meeting of subjective assessments that, in meeting, generate objectively weighted and quantifiable assessments.

This definition of human action and entrepreneurship is flanked by a corresponding idea of socialism.

We shall define «socialism» as any system of institutional aggression on the free exercise of entrepreneurship. By «aggression» or «coercion» we mean all physical violence or threats of physical violence which another person or group of people initiates and employs against the actor. As a result of this coercion, the actor, who otherwise would have freely exercised his entrepreneurship, is forced, in order to avoid greater evils, to act differently than he would have acted in other circumstances, and thus to modify his behaviour and adapt it to the ends of the person or persons who are coercing him. We could consider aggression, when defined in this way, to be the quintessential antihuman action. This is so because coercion keeps a person from freely exercising his entrepreneurship. In other words [...] it prevents a person from pursuing those objectives he discovers and from employing the means he deems within his reach, according to his information or knowledge, to help him achieve them. Therefore, aggression is an evil, because it precludes man from engaging in the activity which is most characteristic of him and which by its essence most intimately befits his nature. (Huerta de Soto, 2010b, p. 49).

Given these definitions, the vision of the Austrian School of Economics suggests that a dynamic equilibrium, where human actions seek to coordinate themselves in order to complete their projects, can be achieved only if those actions are carried out freely. This does not mean that all plans will be brought to fruition made and that a static and perfect equilibrium will be achieved, as assumed by neoclassical theory. Yet, in a free society, individuals have the chance to learn from their mistakes and thereby correct plans and expectations in keeping with what has been learned from the error and the new information content acquired from interaction with other individuals. In the socialist perspective, on the other hand, it is impossible for a central planner to 
gather all the data needed to produce a perfect rational economic calculation. In this way, the central authority, after collecting the necessary information from the minds of individuals, provides all the new information to the players, in terms of prices, the goods to produce, how many, etc.

The Austrians respond to this vision with two main objections, largely and organically developed by the brilliant analysis of Prof. Huerta de Soto. Firstly, the type of information that each subject possesses, of an exclusive character, is by nature tacit and cannot be articulated. This means that it is «logically impossible for this information to be transmitted to the governing body». ${ }^{39}$ In fact, the problem is not merely quantitative; the data is both enormous and dispersed among many individuals, as well impossible to transmit to any planning organ. ${ }^{40}$ This argument, which we could define as static, can be flanked by a dynamic argument: the information available to individuals is not given once and for all; rather, it is continuously modified, so that - in a dynamic process taking place in real time - expectations and plans change with it.

Socialism is impossible, not only because the information actors possess is by its very nature explicitly non-transmissible, but also because, from a dynamic standpoint, when people exercise entrepreneurship, that is, when they act, they constantly create and discover new information. Moreover, it is hardly possible to transmit to the governing body information or knowledge which has not yet been created, but which gradually emerges as a result of the social process itself, to the extent that this process is not assaulted. (Huerta de Soto, 2010b, p. 54).

It is clear, then, that in a socialist system, the mediator role played by the assessments provided by the price system is absent. Since there are no subjective assessments, because everything is determined by the central authorities, prices cannot exist. And without prices there can be no rational economic calculation. In

39 Huerta de Soto (2010b), p. 54.

40 Huerta de Soto (2010b), p. 54. 
a planned society, only numbers imposed from above can exist. But they are not prices. This is because, as we have seen, the essence of price lies in the assessment of the subject. If there is no assessment, there is no price.

As a result, we can see how the nature of the problem does not consist in one system of equations or another to be solved but, rather, in understanding how human action and related knowledge actually take part in the market process. Even if a central planning body had a certain amount of information at its disposition, judged good enough to determine a plan, the fundamental problem is that, once the plan is notified to the individuals, during its implementation the information resumes its dynamic process of change, thereby making the data used to define the plan already «old». Yet this does not mean to say that no plans exist in economic action. Quite the opposite. Plans are continually implemented by individuals in an effort to attain their objectives. And we must not conclude that the knowledge available to individuals is perfect, given and unchangeable. On the contrary, it is constantly changing. However, in the process of interaction between individuals, the dynamic process of acquiring information can take place over time and allow plans to change accordingly, in the ceaseless search for mutual coordination. In a more or less planned system, however, it is assumed that data remain unchanged for a period of time that is long enough to allow the plan to be implemented; this assumption, by evidently distorting reality, contains the core for the failure of every planning experiment.

The general constructivist mistake embodied in the government attempt to plan, control, suggest and direct is clearly explained by Hayek when talking about full employment policies.

The theory which has been guiding monetary and financial policy during the last thirty years, and which I contend is largely the product of such a mistaken conception of the proper scientific procedure, consists in the assertion that there exists a simple positive correlation between total employment and the size of the aggregate demand for goods and services; it leads to the belief that we can permanently assure full employment by maintaining total money expenditure at an appropriate level. Among 
the various theories advanced to account for extensive unemployment, this is probably the only one in support of which strong quantitative evidence can be adduced. I nevertheless regard it as fundamentally false. (Hayek, 2008, pp. 31-32).

Hayek consequently argued that, in the social field, a theory cannot be true merely because it is quantitatively demonstrable. Let's take an example. We could take the distribution of GDP in European countries and, for the same countries, the number of people with large ears. We may, quite by chance, discover a positive correlation between large ears and high rates of growth in GDP. Should one consequently conclude that having large ears stimulates the economy? This is evidently a paradox. What is missing is the scientific logic underlying the question. Nonetheless, econometrics could prove that such a correlation exists and produce a theory, which is «exact» in formal terms but blatantly false from the point of view of logic. And this also helps eliminate the misconception that what can be proven mathematically is also true.

In complex phenomena, fundamental data are often not measurable. If our analysis were to refer only to measurable entities, we would be obliged to restrict the field of investigation to a great extent. It is consequently the case today that those who believe they have a truly scientific approach because they do nothing other than correlate series of data in a search for functional relationships, actually produce theories which are extremely limited and most unlikely to say anything useful about reality. ${ }^{41}$

Consequently, ignorance of true economic science and the presumption that science can only be based on measurable quantities has culminated in producing massive damage in the real world. The presumption of providing exact requirements in

${ }^{41}$ Hayek (2008), p. 42: «I still doubt whether their search for measurable magnitudes has made significant contributions to our theoretical understanding of economic phenomena - as distinct from their value as a description of particular situations. Nor am I prepared to accept the excuse that this branch of research is still very young: Sir William Petty, the founder of econometrics, was after all a somewhat senior colleague of Sir Isaac Newton in the Royal Society!». 
time and space, of being able to determine the level of employment exactly starting from planned fixing of aggregate demand, has created a «very extensive misallocation of resources which is likely to make later large-scale unemployment inevitable». ${ }^{42}$

The Hayekian method does not allow exact forecasts predictions and "provable» cures. Nevertheless, it helps explain the phenomenon of unemployment and a general reading of the effects of inflationary policies on the production system and employment itself.

But the effects on policy of the more ambitious constructions have not been very fortunate and I confess that I prefer true but imperfect knowledge, even if it leaves much indetermined and unpredictable, to a pretense of exact knowledge that is likely to be false. (Hayek, 2008, pp. 43-44).

Yet what are the long term consequences of the pretextual science of those economists who intend to act only by means of measurability? There are certainly erroneous expectations by and about economic scientists. One cannot expect the economy to produce forecasts based on the model of natural sciences. The insistence on the "scientific» method may generate faulty expectations, manipulation and trust in very dangerous social engineering plans. This is the most serious consequence. If the economy is like physics, then why not rely on economists as apprentice sorcerers who, using exact formulas, can generate social welfare, cancel unemployment and distribute wealth equitably? All attempts to do so have led to the construction of earthly hells rather than paradises. ${ }^{43}$ Yet the

welfare of a people, like the happiness of a man, depends on a great many things that can be provided in an infinite variety of combinations. It cannot be adequately expressed as a single end, but only as a hierarchy of ends, a comprehensive scale of values in which every need of every person is given its place. To direct

\footnotetext{
42 Hayek (2008, p. 44).

43 Writes Hölderlin, quoted in Hayek (2006, p. 24): «What has always made the state a hell on earth has been precisely that man has tried to make it his heaven».
} 
all our activities according to a single plan presupposes that every one of our needs is given its rank in an order of values which must be complete enough to make it possible to decide between all the different courses between which the planner has to choose. It presupposes, in short, the existence of a complete ethical code in which all the different human values are allotted their due place. (Hayek, 2006, p. 60).

Yet the problem is that such a comprehensive code of ethics able to organize society in hierarchical terms in accordance with a precise scale of purposes and values, cannot exist and be defined. In particular, it cannot be defined by way of imposition. The State as an organization cannot allow itself to identify such a code of ethics. If such an identification was possible in times when the Empire was a spiritual entity, ${ }^{44}$ capable of harmonizing the common ideals of peoples, today, with the advent of postFrench Revolution nation states, this step is no longer possible. On closer thought, it will be seen that even in the times of the Holy Roman Empire the ideal and spiritual identification of the political entity as a representative of the hierarchy of values came about as the reflection of system of ideas shared at the base of the system itself - and not imposed from above. The Empire was the inevitable form of organization of a vision that arose elsewhere, through sharing a common teleological vision of individual and social action. Without such widespread sharing, reflection in the high level politics simply cannot be implemented. This is why corporatism failed during fascism or at least was unable to perform the function it had during the Middle Ages. The prevailing sociopolitical and ideal system, however, does not allow any organization other than a democratic one; the most one can expect is the shared agreement to define a framework of common rules. For the rest, individuals must be free to act in order to implement their plans.

As we have seen so far, serious analysis of central planning cannot but lead to the conclusion that, in order to be implemented it has to be conducted through more or less accentuated forms

${ }^{44}$ On this topic, see in particular Perez (2004). 
of dictatorship. ${ }^{45}$ The freedom that planners promise is nothing more than freedom from the responsibility of deciding for oneself, freedom from action and from decisions with all the weight of personal responsibility that it entails. ${ }^{46}$ The desire for presumed equality and an easy life can destroy the longing for liberty, because true freedom always implies responsibility.

A society can only progress through free individual action, and economists should be servants to this principle rather than slaves to artificial systems of ideas, ${ }^{47}$ which often become the justification for absurd policies and restricting freedom by ever increasing degrees. Therefore we stress that social scientists should acknowledge that planning cannot be implemented for the overall betterment of society unless the intended goal is collective suffering.

The recognition of the insuperable limits to his knowledge ought indeed to teach the student of society a lesson of humility which should guard him against becoming an accomplice in men's fatal striving to control society - a striving which makes him not only a tyrant over his fellows, but which may well make him the destroyer of a civilization which no brain has designed but which has grown from the free efforts of millions of individuals. (Hayek, 2008, pp. 55-56).

\section{CONCLUDING REMARKS}

In conclusion, we have demonstrated that various academic disciplines have each their own very different concept of what

45 Hayek (2006), pp. 91-92.

46 Hayek (2006), p. 95.

47 Hayek (1992), pp. 53-54: «One's initial surprise at finding that intelligent people tend to be socialists diminishes when one realises that, of course, intelligent people will tend to overvalue intelligence, and to suppose that we must owe all the advantages and opportunities that our civilisation offers to deliberate design rather than to following traditional rules, and likewise to suppose that we can, by exercising our reason, eliminate any remaining undesirable features by still more intelligent reflection, and still more appropriate design and "rational coordination" or our undertakings. This leads one to be favourably disposed to the central economic planning and control that lie at the heart of socialism». 
rationality is, so any debate concerning rationality without first addressing the various denotative and connotative meanings is pointless to say the least. Humans are easily influenced by the framing effect; they often prefer short term pleasure to longterm health (as in the case of harmful drug usage). These are fair critiques of human rationality; we do not deny it. But so what if humans often behave irrationally (or are at least «not well described by the rational-agent model» as Kahneman has put it)? There need not be only two options: 1) irrational and therefore subject to government control or 2) perfectly-rational and therefore allowed to be free. There is at least one alternative option that seems to be largely ignored in academia: free to err, learn, and shape one's own destiny - regardless of what others may label as rational or irrational.

We point out the flawed logic of the economic and political solutions offered by many of the critics of free markets. To remind the reader, the argument usually goes as follows: Humans behave irrationally; therefore governments should control human action. The error lies in forgetting that governments only exist and only take any action at all because of the actions of the individuals that comprise them. So if it is concluded that individuals behave irrationally, then so do governments (or more specifically, the individual actors comprising governments behave irrationally). What is more, Cass Sunstein - one of most prominent intellectuals that has gained a great deal of attention in recent years for his proposed government solutions to the human irrationality problem - went on to become a central planner himself and has contradicted his own «libertarian» solutions to the irrationality problem in at least one of his other books. This is to us - to put it in Sowellian terms - revealing of an Unconstrained/Utopian Vision, which seems to underlie not only his beliefs but also of many like him.

In this paper we have defined humans as purposeful actors rather than rational agents. The word «rational» is too open to ambiguity. This implies expectations and plans. Plans are based on the present knowledge and accomplished over time. But in a process that happens in time, the content of knowledge, dispersed among millions of individuals, is continuously changing, according to the 
keleidic view of Lachmann. This means that expectations and plans are also continuously revised. Every action implies choices that are «rational» ex ante, because they are consistent with the available knowledge, but these actions are continuously revised because of the mutable character of knowledge.

On this basis, any government plan is inconceivable for the simple fact that in a free society the content of information can flow among human beings, bringing them to revise their plans and actions (which is how the price mechanism works). By contrast, government action is necessarily static but is based on information that is not static at all. So the transmission of knowledge, due to government intervention, becomes impossible, avoiding the coordination process among individual plans.

Therefore, accepting the concept of purposeful action is to affirm the very subjective nature of human behavior.

The market process is the outward manifestation of an unending stream of knowledge. [...] The pattern of knowledge is continuously changing in society, a process hard to describe. Knowledge defies all attempts to treat it as a «datum» or an object in time and space. (Lachmann, 1976b, p. 127).

Embracing this view means to reject any government intervention option, because of «the «dark forces of time and ignorance» that engulf us all». 48

\section{BIBLIOGRAPHICAL REFERENCES}

Becker, G., AND Murphy, K. (1988): «A Theory of Rational Addiction», Journal of Political Economy, vol. 96, n.․․ 4, pp. 675-700.

Bastiat, F. (2007): «The Law». In F. Bastiat, The Bastiat Collection, vol. I, Ludwig von Mises Institute: Auburn, pp. 49-94.

BoetTKe, P.J., AND Sullivan, S.T. (1998): «Lachmann's Policy Activism. An Austrian critique of Keynesian proclivities». In R. Koppl, and G. Mongiovi, eds., Subjectivism and Economic

48 Boettke and Sullivan (1998), p. 179. 
Analysis. Essays in memory of Ludwig M. Lachmann. Routledge: London and New York, pp. 163-182.

Ferlito, C. (2013): Phoenix Economics. From Crisis to Renascence, Nova Publishers: New York.

FRIEDMAN, D. (2011): «Market Failure: An Argument for and Against

Government». Speech at The Future of Freedom Foundation's «Economic Liberty Lecture Series».

F.D. Roosevelt American Heritage Center. Web. 2 Jan 2014. <http://www.fdrheritage.org/bill_of_rights.htm>.

Friedman, M., AND Friedman, R.D. (1979): Free to Choose. A Personal Statement, Harvest: Eugene.

GoldSTEIN, J.S., AND WHITwORTH, S. (2005): International Relations, Longman Publishing Group: London.

HAYeK F.A. von (1964): Scientism and the Study of Society. In F.A. von Hayek, The Counter-Revolution of Science. Studies on the Abuse of Reason. The Free Press of Glencoe: New York, pp. 11102.

- (1992): The Collected Works of Friedrich August Hayek, vol. I: The Fatal Conceit. The Errors of Socialism, Routledge: London.

- (2006): The Road to Serfdom, Routledge: New York.

- (2008): The Pretence of Knowledge. In F.A. von Hayek, A Free-Market Monetary System, Ludwig von Mises Institute: Auburn, pp. 29-56.

HiCKS, J.R. (2002): «Is Interest the Price of a Factor of Production?». In P. Boettke and S. Boehm, eds., Modern Austrian Economics. Archeology of a Revival, vol. II: The Age of Dispersal, Pickering \& Chatto: London, pp. 281-295.

Huerta De Soto, J. (2010a): The Austrian School. Market Order and Entrepreneurial Creativity, Edward Elgar: Cheltenham and Northampton.

- (2010b): Socialism, Economic Calculation and Entrepreneurship, Edward Elgar: Cheltenham and Northampton.

HÜlsmanN, J.G. (2000): «A Realist Approach to Equilibrium Analysis», The Quarterly Journal of Austrian Economics, vol. 3, n.․ 4, pp. 3-51.

KaHNEMAN, D. (2003): «A Perspective on Judgment and Choice. Mapping Bounded Rationality», American Psychologist, vol. 58, n. 9 9, pp. $697-720$. 
- (2011): Thinking, Fast and Slow. Farrar, Straus and Giroux: New York.

LachmanN, L.M. (1976a): «From Mises to Shackle: An Essay on Austrian Economics and the Kaleidic Society», Journal of Economic Literature, vol. 14, n. ${ }^{\circ}$ 1, pp. 54-62.

- (1976b): «On the central concept of Austrian economics: market process». In E.G. Dolan, ed., The Foundations of Modern Austrian Economics, Institute for Humane Studies: Menlo Park, pp. 126-132.

- (1978): Capital and Its Structure. Sheed Andrews and McMeel: Kansas City.

- (1979): «Comment: Austrian Economics Today». In M.J. Rizzo, ed.,Time, Uncertainty, and Disequilibrium. Exploration of Austrian Themes. D.C. Heath and Company: Lexington, pp. 64-69.

- (2002): «Why Expectations Matter». In S. Gloria-Palermo, ed., Modern Austrian Economics. Archeology of a Revival, vol. I: A MultiDirectional Revival, Pickering \& Chatto: London, pp. 251-269.

Mises, L. von (1998): Human Action, Ludwig von Mises Institute: Auburn.

- (2008): Human Action, Ludwig von Mises Institute: Auburn.

O'Driscoll, G., AND Rizzo, M.J. (2002): The Economics of Time and Ignorance, Routledge: London and New York.

Perez, G. (2004): "“Federalismo imperiale" e "Stato nazionale" negli scritti politici di Julius Evola». In J. Evola, Il Federalismo imperiale. Scritti sull'idea di Impero 1926-1953. Fondazione Julius Evola and Controcorrente: Rome and Naples, pp. 9-56.

Phaneuf, E. (2013): «Sowell's Visions», The Freeman, 5 December, http:/ / www.fee.org/the_freeman/detail/sowells-visions.

PINKER, S. (2002): The Blank Slate: The Modern Denial of Human Nature, Penguin Books: New York.

- (2007): The Stuff of Thought: Language as a Window into Human Nature, Penguin Group: New York.

- (2011): The Better Angels of Our Nature: Why Violence Has Declined, Penguin Group: New York.

Rand, A. (1964): The Virtue of Selfishness: A New Concept of Egoism, Penguin Books: New York.

Rizzo, M.J., ed. (1979a): Time, Uncertainty, and Disequilibrium. Exploration of Austrian Themes. D.C. Heath and Company: Lexington. 
— (1979b): «Disequilibrium and All That: An Introductory Essay». In Rizzo (1979a), pp. 1-18.

- (2002): «Equilibrium Visions». In P. Boettke and S. Boehm, eds., Modern Austrian Economics. Archeology of a Revival, vol. II: The Age of Dispersal, Pickering \& Chatto: London, pp. 175-190.

RoBINSON, P. (2008): «Transcript: Peter M. Robinson Interviews Thomas Sowell on A Conflict of Visions. Uncommon Knowledge with Peter Robinson». Hoover Institution, 27 October. Web 27 November 2013, http:/ / media.hoover.org/documents/uk_ sowell_transcript_conflict_visions.pdf.

SAAD, G. (2011): The Consuming Instinct: What Juicy Burgers, Ferraris, Pornography, and Gift Giving Reveal About Human Nature. Prometheus Books: New York.

SHACKLE, G.L.S. (2009): Epistemics and Economics: A critique of economic doctrines. Transaction Publishers: New Brunswick and London.

Schulak, E.M., And Unterköfler, H. (2011): The Austrian School of Economics. A History of Its Ideas, Ambassadors, and Institutions, Ludwig von Mises Institute: Auburn.

SOWELL, T. (2007): A Conflict of Visions: Ideological Origins of Political Struggles, Basic Books: New York.

SunsteIn, C.R. (2004): The Second Bill of Rights: FDR's Unfinished Revolution-And Why We Need It More Than Ever, Basic Books: New York.

ThaleR, R.H., AND SunsteIn, C.R. (2008): Nudge: Improving Decisions About Health, Wealth, and Happiness, Yale University Press: New Haven. 
